\title{
Use of size-based production and stable isotope analyses to predict trophic transfer efficiencies and predator-prey body mass ratios in food webs
}

\author{
Simon Jennings*, Karema J. Warr, Steve Mackinson \\ Centre for Environment, Fisheries \& Aquaculture Science, Lowestoft Laboratory, Suffolk NR33 0HT, United Kingdom
}

\begin{abstract}
Methods of assessing the structure and function of food webs are needed to provide a basis for assessing large-scale direct (e.g. fisheries) and indirect (e.g. climate change) effects of human activities on marine ecosystems. We present a simple synthesis of the complex structure and function of a real marine food web, based on analyses of body size distributions, production-body size relationships and trophic level-body size relationships. We show how size-based estimates of production, species richness and trophic level (from nitrogen stable isotope analysis) can be used to quantify trophic transfer efficiency, mean predator-prey body-mass ratios and the mean ratio of the number of predator to prey species in marine food webs. We applied these methods to the central North Sea, and estimated transfer efficiencies of 3.7 to $12.4 \%$, a mean predator-prey body-mass ratio of 109:1 and a mean ratio of the number of predator to prey species of 0.34 . We conducted sensitivity analyses to show how differences in the fractionation of $\delta^{15} \mathrm{~N}$ and changes in the slope of the relationship between production and $\delta^{15} \mathrm{~N}$ affected our predictions. Our estimates of transfer efficiency and mean predator-prey body-mass ratios are similar to those obtained by costly and labour-intensive diet- and ecosystem-modelling studies. Coupled analyses of size and trophic structure may provide a method for validating ecosystem models and assessing human impacts on marine ecosystems.
\end{abstract}

KEY WORDS: Body size · Food web · Transfer efficiency · Stable isotope analysis · Production · Diversity

\section{INTRODUCTION}

The principle primary producers in marine ecosystems are small unicellular algae (Duarte \& Cebrián 1996), and these support strongly size-structured foodchains where most predators are larger than their prey (Pope et al. 1994). Since many marine species will grow in mass by 5 or more orders of magnitude during their life cycle (Cushing 1975), and since cannibalism, cross-predation and transient predator-prey relationships are common (Pope et al. 1994, Boyle \& Bolettzky 1996), there are compelling reasons to adopt size rather than species-based analyses of marine food

*E-mail: s.jennings@cefas.co.uk webs (Sheldon et al. 1972, Kerr 1974). Body size determines potential predators and prey (Cohen et al. 1993), rates of production and natural increase (Banse \& Moser 1980, Brey 1999), energy requirements (Boudreau et al. 1991) and vulnerability to mortality (Jennings et al. 1998).

Biomass size-spectra (plots of biomass as log bodymass class vs log body-mass class) have been used to describe the structure of aquatic ecosystems (Sheldon et al. 1972, Kerr 1974, Pope et al. 1988, Duplisea \& Kerr 1995, Rice \& Gislason 1996), and models of these sizespectra assume that biomass and production decrease in progressively heavier body-mass classes due to the inefficient transfer of carbon from prey to predators (Dickie et al. 1987, Thiebaux \& Dickie 1992). This implies that heavier size-classes are higher in the 
trophic continuum, a pattern demonstrated empirically for plankton (Fry \& Quinones 1994), benthic invertebrate (France et al. 1998) and fish (Jennings et al. 2002) communities. The trophic continua across body sizeclasses also show that fixed (integer) trophic levels do not appropriately describe the structure of aquatic food webs, and trophic level can thus refer to any point on the continuum.

Estimates of trophic transfer efficiency are needed to estimate unknown fluxes in production models, the potential yields of fisheries and the proportion of primary production required to sustain them (e.g. Pauly \& Christensen 1995). Trophic transfer efficiency (TE) describes the proportion of prey production that is converted to predator production $\left(\mathrm{TE}=P_{\mathrm{c}} / P_{\mathrm{p}}\right.$, where $P_{\mathrm{c}}$ is predator production and $P_{\mathrm{p}}$ is prey production). Since body mass is correlated with specific production (Banse \& Moser 1980), biomass size-spectra can be parameterised to give production by body-mass class (Platt \& Denman 1978, Gaedke \& Straile 1994, Duplisea $\&$ Kerr 1995). If mean predator-to-prey mass ratios can be estimated, then trophic transfer efficiency can be determined from the slope of the production size spectrum (e.g. Gaedke \& Straile 1994). However, if trophic level at body mass is known, TE could be calculated without knowing the mean predator-prey body-mass ratio. This is because the slope of the relationship between trophic level and production at body size is the TE and the slope of the relationship between trophic level and body mass is the mean predator-prey body-mass ratio (as an output).

Trophic level can be estimated using nitrogen stable isotope analysis (Owens 1987), because the abundance of $\delta^{15} \mathrm{~N}$ in the tissues of predators is enriched relative to their prey (Minagawa \& Wada 1984, Peterson \& Fry 1987, Cabana \& Rasmussen 1996, Post et al. 2000, Post 2002). Indeed, Fry \& Quinones (1994), France et al. (1998) and Jennings et al. (2002) have already used nitrogen stable isotope analysis to show that the trophic levels of plankton, invertebrates and fishes in biomass size-spectra increase continuously with increasing body size. Nitrogen stable isotope analysis is preferable to diet analysis for estimating trophic levels in many marine food webs because most species switch their diet frequently, prey on species that are digested at different rates, have gut contents that cannot be identified, or regurgitate gut contents on capture (Staniland et al. 2001, Polunin \& Pinnegar 2002). The abundance of $\delta^{15} \mathrm{~N}$ reflects the composition of the assimilated diet and integrates differences in assimilated diet over time (Minagawa \& Wada 1984, Hobson \& Welch 1992, Post 2002).

Broadly constant ratios of the number of predator to prey species may be a general property of parts of some food webs (Briand \& Cohen 1984, Jeffries \&
Lawton 1985). While such ratios cannot be determined accurately in food webs with taxonomic aggregation (Pimm 1982, Link 2002), ratios have been determined from species lists and knowledge of diet (Jeffries \& Lawton 1985). In freshwater communities, these ratios range from 0.48 in species-poor collections to 0.29 in species-rich collections, with a mean of 0.36 (Jeffries \& Lawton 1985). If relationships between body size, diversity and trophic structure can be described, then the slope of the relationship between trophic level and species richness at a given body size is the ratio of the mean number of predator to prey species.

In a previous paper, we used isotope analyses and size-spectra to describe trophic relationships within and among species and to describe the relationship between the size and trophic structure of a benthic fish and invertebrate community (Jennings et al. 2002). However, in this analysis, it was not possible to consider all pathways of energy flow through the food web, since some species of infauna and pelagic fish that interact with the benthic community, and contribute to production, were excluded. Here, we extend the population- and community-based approaches of Jennings et al. (2002) to the ecosystem, and quantify the abundance, diversity and $\delta^{15} \mathrm{~N}$ of all major groups of animals within a defined size range. We use these new data to integrate size-based production, diversity and stable isotope analyses and to establish relationships between production, diversity and trophic structure. We show that estimates of TE and predator-prey mass ratios derived from size-based analyses are comparable with those based on more data-intensive methods.

\section{MATERIALS AND METHODS}

We estimated the mean biomass and size distributions of all animals from 2 to $2048 \mathrm{~g}$ wet mass (excluding seabirds) in an area of the central North Sea from $54^{\circ} 00^{\prime}$ to $55^{\circ} 00^{\prime} \mathrm{N}$ and $00^{\circ} 30^{\prime}$ to $02^{\circ} 00^{\prime} \mathrm{E}$. While animals of $<2 \mathrm{~g}$ wet mass will account for most of the production in the marine ecosystem (e.g. Cushing 1975), we chose not to work with smaller animals for 2 reasons. First, the short-term (days, weeks) variability in the dynamics of plankton, meiofauna, small fishes and invertebrates means that they have to be sampled at intervals of a few weeks or less to produce meaningful time-averaged size-spectra (e.g. Pope et al. 1994). Second, the $\delta^{15} \mathrm{~N}$ of plankton and other small animals is highly variable and very frequent sampling is required to integrate this variability over the course of the production cycle (e.g. Rolff 2000). We did not have the resources (ship time) to sample very frequently and at large spatial scales and so we worked with larger ani- 
mals ( $\geq 2 \mathrm{~g}$ in the case of the present study) that would integrate variability in the production dynamics and $\delta^{15} \mathrm{~N}$ of their smaller prey and would provide adequate time-averaged size and trophic spectra when sampled 2 times per year.

We used corers, dredges and nets to take haphazardly located replicate samples of infaunal invertebrates, epifaunal invertebrates, bottom-dwelling fishes and pelagic fishes or squid in autumn 2000 and spring 2001. The frequency of sampling with each gear, the methods of estimating abundance and the size ranges of animals sampled by each gear are described in Table 1. All individual animals in each replicate sample taken with each gear were weighed at sea and assigned to $\log _{2}$ size-classes. Weighing was done with calibrated Pols heave compensated balances with a resolution of $0.1 \mathrm{~g}$ and minimum accuracy of $0.2 \mathrm{~g}$. We sorted infauna from the core/anchor dredge samples and invertebrate epifauna from the $2 \mathrm{~m}$ beam-trawl samples. Epifauna were defined as those species that live on the seabed or bury in it temporarily, while infauna were defined as those that live predominantly in the sediment.

We estimated the mean trophic level for the animals in each size-class using stable isotope analysis. Since each size-class of infauna and epifauna contained many animals of many species, comparable tissues could not be sampled, and all individuals that were sampled with each gear in each size-class were homogenised in an electric blender. The size of the blenders used to homogenise the animals depended on the number of animals assigned to each size-class, and ranged from 0.25 to $2.5 \mathrm{l}$. Animals were homogenised whole, although shells were removed from infauna (Bivalvia) and hermit crabs (Paguridae). Approximately $4 \mathrm{~g}$ of homogenate was frozen at $-30^{\circ} \mathrm{C}$ and retained for stable isotope analysis. For fishes in larger size classes (typically $>32 \mathrm{~g}$ ) we dissected a sample of white muscle from the dorsal musculature of each individual. Each fish was weighed before the sample was taken, and the sample size was set at a fixed percentage of body weight in each size-class, following the procedure described by Jennings et al. (2001b). The tissue from fishes in each size-class was combined and homogenised in a blender, or crushed and ground manually, to produce a smooth paste. Approximately $4 \mathrm{~g}$ of paste was retained and immediately frozen at $-30^{\circ} \mathrm{C}$.

The biomass and size-distribution of small pelagic fishes, predominantly sandeels, was estimated using acoustic methods (Table 1). For these fishes, we predicted trophic level from a relationship between trophic level and $\log _{2}$ body mass for sandeels caught with nets in the same area $\left(\delta^{15} \mathrm{~N} \%\right.$ o $=\left[0.24 \log _{2}\right.$ body mass] + 11.4). Biomass density by size-class for all animal groups was calculated as $B=(C / A) \times a c$, where $B$

Table 1. Equipment, methods and assumptions used to estimate the abundance of faunal groups. All sampling was conducted from the CEFAS research vessels 'Corsytes' and 'Cirolana'. Sampling design: Years (seasons) $\times$ Sites $\times$ Replicates within sites, sites were $1 \mathrm{n}$ mile ${ }^{2}$ boxes for NIOZ core, anchor dredge and $2 \mathrm{~m}$ beam-trawl sampling; Area: area of replicate; Availability: proportion of total abundance of animals in group assumed to be in path of gear; Catch efficiency: proportion of animals in path of gear that are assumed to be caught. NIOZ: Netherlands Institute for Sea Research corer; GOV: Grande Ouverture Verticale otter trawl towed for 30 min at 4 knots (Knijn et al. 1993); na: not applicable

\begin{tabular}{|c|c|c|c|c|c|}
\hline Group & Size-class & Gear & Sampling design & Area & $\begin{array}{l}\text { Availabilityc/ } \\
\text { catch efficiency }\end{array}$ \\
\hline Infauna & $>2 g^{a}$ & NIOZ core & $2 \times 12$ & $a^{2}$ & $1.0 /$ \\
\hline Infauna & $>2 \mathrm{~g}^{\mathrm{a}}$ & Anchor dredge & $2 \times 12 \times 3$ & $n a^{b}$ & $n a^{b}$ \\
\hline Epifauna & $>2 \mathrm{~g}^{\mathrm{a}}$ & $2 \mathrm{~m}$ beam trawl ( $2 \mathrm{~mm}$ mesh) & $2 \times 12 \times 3$ & $400 \mathrm{~m}^{2}$ & $1.0 / 0.5$ \\
\hline Small demersal fishes/squid & $>2-8 \mathrm{~g}$ & $2 \mathrm{~m}$ beam trawl ( $2 \mathrm{~mm}$ mesh) & $2 \times 12 \times 3$ & $400 \mathrm{~m}^{2}$ & $1.0 / 0.5$ \\
\hline Large demersal fishes/squid & $\mathrm{d}^{\mathrm{d}}>8 \mathrm{~g}$ & $4 \mathrm{~m}$ beam trawl (20 mm mesh) & $2 \times 12 \times 1$ & $14824 \mathrm{~m}^{2}$ & $1.0 / 0.5$ \\
\hline Large fishes/squid ${ }^{\mathrm{d}}$ & $>4 \mathrm{~g}$ & GOV trawl (20 mm mesh) & $2 \times 3 \times 1$ & variable $^{\mathrm{c}}$ & 0.5 \\
\hline Small pelagic fishes & $>2 \mathrm{~g}$ & Acoustics $^{\mathrm{e}}$ & na: grid survey ${ }^{\mathrm{f}}$ & $2895 \mathrm{~km}^{2}$ grid $^{\mathrm{f}}$ & $1.0 / 1.0$ \\
\hline \multicolumn{6}{|c|}{$\begin{array}{l}\text { aShell free wet weights recorded for bivalve molluscs. The wet weights of bivalves (Bivalvia) and hermit crabs (Paguridae) } \\
\text { exclude shells }\end{array}$} \\
\hline \multicolumn{6}{|c|}{$\begin{array}{l}{ }^{\mathrm{b}} \text { Anchor dredge was used to obtain samples of infauna for stable isotope analysis, but not for abundance estimates } \\
\text { cGeometry of net is not fixed }\end{array}$} \\
\hline \multicolumn{6}{|c|}{${ }^{\mathrm{d}}$ Fish catches from the $4 \mathrm{~m}$ beam and GOV trawls were subsampled for stable isotope analysis } \\
\hline \multicolumn{6}{|c|}{$\begin{array}{l}\text { eSurveyed with Simrad EK500 scientific echosounder operating at } 38 \text { and } 120 \mathrm{Khz} \text {, calibrated according to standard methods } \\
\text { (Foote et al. 1987). Post-processing of echosiginals was performed using EchoView software (Sonardata). Biomass estimates } \\
\text { were derived from } 120 \mathrm{kHz} \text { echo integration data following MacLennan \& Simmonds (1992) and MacLennan \& Fernandes } \\
\text { (2000). Target strengths were taken from unpublished tests and length-frequency data from pelagic trawl samples } \\
\text { f }\end{array}$} \\
\hline
\end{tabular}


Table 2. Biomass of sampled groups by $\log _{2}$ body-mass class. Mean (SD) biomass ( $\mathrm{g}$ wet wt $\mathrm{m}^{-2}$ )

\begin{tabular}{|c|c|c|c|c|c|c|c|c|c|c|}
\hline \multirow[t]{2}{*}{ Group } & \multicolumn{10}{|c|}{ Body mass (midpoint $\log _{2}$ ) } \\
\hline & 1.5 & 2.5 & 3.5 & 4.5 & 5.5 & 6.5 & 7.5 & 8.5 & 9.5 & 10.5 \\
\hline $\begin{array}{l}\text { Infauna (NIOZ core) } \\
\text { (excluding spatangoids) }\end{array}$ & $\begin{array}{c}1.62 \\
(3.00)\end{array}$ & & & & & & & & & \\
\hline Epifauna ( $2 \mathrm{~m}$ beam trawl) & $\begin{array}{l}1.69 \\
(0.24)\end{array}$ & $\begin{array}{c}2.58 \\
(0.25)\end{array}$ & $\begin{array}{c}2.60 \\
(0.33)\end{array}$ & $\begin{array}{c}2.15 \\
(0.41)\end{array}$ & $\begin{array}{c}1.65 \\
(0.38)\end{array}$ & $\begin{array}{c}1.11 \\
(0.34)\end{array}$ & $\begin{array}{c}0.38 \\
(0.14)\end{array}$ & & & \\
\hline Fishes ( $2 \mathrm{~m}$ beam trawl) & $\begin{array}{c}0.14 \\
(0.04)\end{array}$ & $\begin{array}{c}0.37 \\
(0.10)\end{array}$ & & & & & & & & \\
\hline Fishes ( $4 \mathrm{~m}$ beam trawl) & & $\begin{array}{c}0.22 \\
(0.03)\end{array}$ & $\begin{array}{l}0.26 \\
(0.0 .07)\end{array}$ & $\begin{array}{c}0.80 \\
(0.15)\end{array}$ & $\begin{array}{c}0.88 \\
(0.19)\end{array}$ & $\begin{array}{l}1.10 \\
(0.22)\end{array}$ & $\begin{array}{c}0.32 \\
(0.08)\end{array}$ & $\begin{array}{c}0.16 \\
(0.04)\end{array}$ & $\begin{array}{l}0.11 \\
(0.0 .04)\end{array}$ & \\
\hline Fishes (GOV trawl) & & $\begin{array}{c}0.32 \\
(0.28)\end{array}$ & $\begin{array}{c}0.45 \\
(0.28)\end{array}$ & $\begin{array}{c}0.44 \\
(0.25)\end{array}$ & $\begin{array}{c}0.79 \\
(0.22)\end{array}$ & $\begin{array}{l}1.05 \\
(0.40)\end{array}$ & $\begin{array}{c}1.09 \\
(0.53)\end{array}$ & $\begin{array}{c}0.16 \\
(0.07)\end{array}$ & $\begin{array}{c}0.02 \\
(0.02)\end{array}$ & $\begin{array}{c}0.01 \\
(0.01)\end{array}$ \\
\hline Fishes (acoustics) & $\begin{array}{l}1.73 \\
(1.04)\end{array}$ & $\begin{array}{c}2.90 \\
(0.90)\end{array}$ & $\begin{array}{c}1.73 \\
(0.43)\end{array}$ & $\begin{array}{c}0.52 \\
(0.59)\end{array}$ & $\begin{array}{c}0.01 \\
(0.01)\end{array}$ & & & & & \\
\hline
\end{tabular}

is biomass, $C$ is catch, $A$ is area swept or sampled by gear, $a$ is the availability of the target group to the gear and $c$ is the catchability of the target group in the path of gear (Table 1). The biomass of infauna was estimated from core samples (Table 1), but for infaunal stable isotope analysis we collected infauna at the same sites using an anchor dredge.

We calculated the total biomass of animals in each body-mass class as the sum of the biomass estimates from the different sampling gears. We assumed that the NIOZ (Netherlands Institute for Sea Research) corer/anchor dredge, beam trawls, GOV trawl (Grande Ouverture Verticale otter trawl) and acoustic survey all sampled different groups of animals, and summed biomass estimates for all these gears across size classes. This assumption is completely valid for the invertebrate infauna and epifauna that were sorted after sampling, but there will be a large overlap in the composition of demersal fish catches taken with the 2 and $4 \mathrm{~m}$ beam trawls. Accordingly, we only included fish of 2 to $8 \mathrm{~g}$ from the $2 \mathrm{~m}$ beam-trawl samples and fish $>8 \mathrm{~g}$ from the $4 \mathrm{~m}$ beam-trawl samples (Table 1). There will also be a small overlap in the composition of demersal fish catches taken with the $4 \mathrm{~m}$ beam and GOV trawls, since both these gears will catch flatfishes and gadoids living on or near the seabed. However, studies of the catch efficiency of the GOV trawl for the closely bottom-associated flatfishes, that are caught most effectively with beam trawls, suggest that the extent of the overlap will be minor (e.g. Sparholt 1990).

Individual body mass was converted to production using a cross-species relationship between biomass and production $(P)$ to biomass $(B)$ ratios derived from the compilation of Brey (1999). The relationship was $\log _{10} P: B=-0.233 \log _{10} B-0.197$, and the validity of the cross-species $P: B$ vs body-mass relationship has been verified using a phylogenetic comparative approach (Jennings et al. 2001a). For fish, $P: B$ ratios were taken as $4 \times$ those of invertebrates (Banse \& Moser 1980). We excluded the production of burrowing urchins (spatangoids) from our analysis, even though they accounted for production of $9.6 \mathrm{~g} \mathrm{~m}^{-2} \mathrm{yr}^{-1}$. This is because the pro-

Table 3. $\delta^{15} \mathrm{~N}$ of sampled groups by $\log _{2}$ body-mass class. Mean (SD) $\delta^{15} \mathrm{~N}(\%)$

\begin{tabular}{|c|c|c|c|c|c|c|c|c|c|c|}
\hline \multirow[t]{2}{*}{ Group } & \multicolumn{10}{|c|}{ Body mass (midpoint $\log _{2}$ ) } \\
\hline & 1.5 & 2.5 & 3.5 & 4.5 & 5.5 & 6.5 & 7.5 & 8.5 & 9.5 & 10.5 \\
\hline $\begin{array}{l}\text { Infauna (NIOZ core) } \\
\quad \text { (excluding spatangoids) }\end{array}$ & $\begin{array}{c}8.00 \\
(1.73)\end{array}$ & & & & & & & & & \\
\hline Epifauna ( $2 \mathrm{~m}$ beam trawl) & $\begin{array}{l}10.59 \\
(0.80)\end{array}$ & $\begin{array}{l}11.08 \\
(0.74)\end{array}$ & $\begin{array}{l}11.45 \\
(0.71)\end{array}$ & $\begin{array}{l}11.51 \\
(0.60)\end{array}$ & $\begin{array}{l}12.08 \\
(1.41)\end{array}$ & $\begin{array}{l}13.15 \\
(1.59)\end{array}$ & $\begin{array}{c}11.54 \\
-\end{array}$ & & & \\
\hline Fish ( $2 \mathrm{~m}$ beam trawl) & $\begin{array}{l}10.92 \\
(0.98)\end{array}$ & $\begin{array}{l}11.75 \\
(1.01)\end{array}$ & & & & & & & & \\
\hline Fish (4 m beam trawl) & & $\begin{array}{l}13.11 \\
(0.51)\end{array}$ & $\begin{array}{l}13.09 \\
(0.28)\end{array}$ & $\begin{array}{l}13.58 \\
(0.42)\end{array}$ & $\begin{array}{l}13.95 \\
(0.57)\end{array}$ & $\begin{array}{l}14.29 \\
(0.56)\end{array}$ & $\begin{array}{l}14.44 \\
(0.60)\end{array}$ & $\begin{array}{l}14.36 \\
(1.29)\end{array}$ & $\begin{array}{l}15.37 \\
(0.78)\end{array}$ & \\
\hline Fish (GOV trawl) & & $\begin{array}{l}12.30 \\
(0.37)\end{array}$ & $\begin{array}{l}12.45 \\
(0.72)\end{array}$ & $\begin{array}{l}12.49 \\
(0.56)\end{array}$ & $\begin{array}{l}12.79 \\
(0.58)\end{array}$ & $\begin{array}{l}13.35 \\
(0.67)\end{array}$ & $\begin{array}{c}13.50 \\
(0.68)\end{array}$ & $\begin{array}{l}13.46 \\
(0.71)\end{array}$ & $\begin{array}{l}15.00 \\
(0.61)\end{array}$ & $\begin{array}{c}15.37 \\
-\end{array}$ \\
\hline Fish (acoustics) & 11.76 & 12.00 & 12.24 & 12.48 & 12.72 & & & & & \\
\hline
\end{tabular}


duction of these large deposit-feeders feeding at a low trophic level (mean $\delta^{15} \mathrm{~N}=7.43-7.81 \%$ in size-classes of 4 to $16 \mathrm{~g}$ ) appeared to be decoupled from the rest of the food web we considered, and the production of burrowing urchins is largely recycled in the sediment by bacteria and meiofauna.

For stable isotope analysis, the frozen tissue from each target group and size-class was freeze-dried and ground to a fine powder (particles $<60 \mu \mathrm{m}$ ). Samples of powder (1 mg) were weighed into a tin capsule, and the ${ }^{15} \mathrm{~N}$ composition was determined using continuousflow isotope ratio mass spectrometry (Preston \& Owens 1983: PDZ-Europa Integra-CN system). Two samples of reference material (a standard mix of ammonium sulphate and beet sugar) were analysed after every 5 tissue samples to calibrate the system and compensate for drift. The ${ }^{15} \mathrm{~N}$ composition was expressed in conventional delta notation, relative to the level of ${ }^{15} \mathrm{~N}$ in atmospheric $\mathrm{N}_{2}$. Experimental precision was $0.1 \%$ (standard deviation of $\delta^{15} \mathrm{~N}$ for replicates of reference material).

Estimates of species richness in body-mass classes were based on all available records of infauna, epifauna and fish species that have been sampled in the study area since 1977. These records included ICES (International Council for the Exploration of the Seas) co-ordinated fish and benthos surveys (ICES unpubl. data, Heip et al. 1992, Knijn et al. 1993), the European Community-funded epibenthic survey of the North Sea (R. Callaway unpubl. data) and CEFAS (Centre for Environment, Fisheries and Aquaculture Science) research programmes (T. Dinmore \& S. Jennings unpubl. data). We used a wide range of records over a long time period to ensure that estimates of maximum body mass were not primarily a function of the direct or indirect effects of fishing and to ensure that rare species were represented in our analysis. The absence of rare species in the samples we used for production and trophic level estimates will have little effect on these estimates because rare species account for a very small proportion of biomass and production. We assigned a maximum body mass $(\mathrm{g})$ to all species and, with the exception of a few fishes that produce large egg cases or live young (elasmobranchs), we assumed that species would be present in their terminal (largest) body-mass class and all smaller classes. This is an appropriate assumption when predation is strongly size-based and cannibalism is common (Pope et al. 1994).

\section{RESULTS}

Biomass and $\delta^{15} \mathrm{~N}$ estimates for all size classes (Tables 2 \& 3) enabled us to predict production and
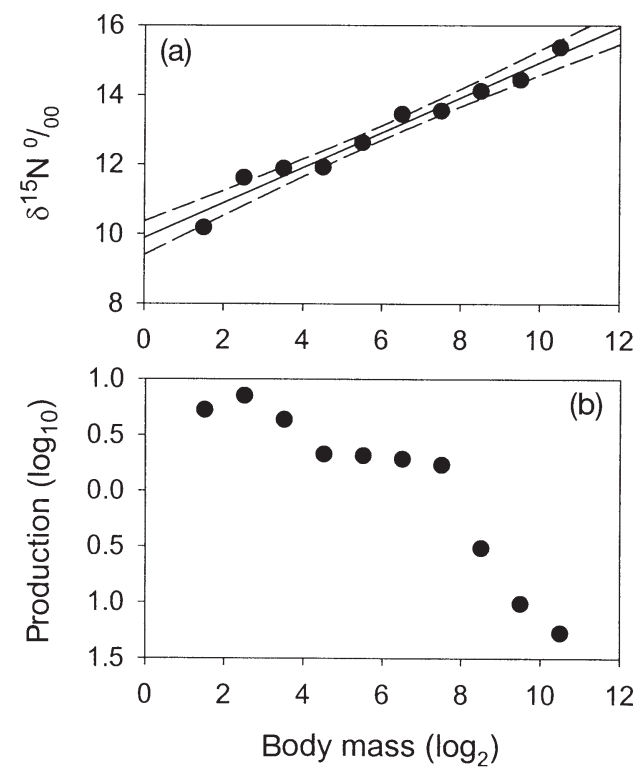

Fig. 1. Relationships between (a) biomass-weighted mean $\delta^{15} \mathrm{~N}(\%)$ and $\log _{2}$ body mass, and (b) $\log _{10}$ production $\left(\mathrm{g} \mathrm{m}^{-2}\right.$ $\mathrm{yr}^{-1}$ ) and $\log _{2}$ body mass for all faunal groups

weighted mean $\delta^{15} \mathrm{~N}$ across all animal groups. Total biomass and production by animals with a body mass of 2 to $2048 \mathrm{~g}$ were estimated as 29.3 and $25 \mathrm{~g} \mathrm{~m}^{-2} \mathrm{yr}^{-1}$ respectively, with $20 \mathrm{~g} \mathrm{~m}^{-2} \mathrm{yr}^{-1}$ of this production attributable to fishes. Biomass-weighted mean $\delta^{15} \mathrm{~N}$, calculated across all faunal groups, increased significantly with increasing body mass (Fig. 1a). If we assume that there is a $3.4 \%$ enrichment in $\delta^{15} \mathrm{~N}$ per trophic level (Minagawa \& Wada 1984, Post 2002), then the relationship between trophic level and body mass $\left(\delta^{15} \mathrm{~N} \%=9.88+0.50 \log _{2} \mathrm{M}_{;} F_{1,8}=227.6, \mathrm{r}^{2}=\right.$ $0.97, \mathrm{p}<0.001$ ) implies that the mean predator-to-prey body-mass ratio in the community was 109:1 (mass ratio $=2^{3.4 / \text { slope }}$ ).

The relationship between body mass and production suggested that production decreased increasingly fast with increasing mass in larger body-mass classes (Fig. 1b). The relationship between production and $\delta^{15} \mathrm{~N}$ by size-class was highly significant (Fig. 2a; $\log _{10} \mathrm{P}=5.48-0.420 \delta^{15} \mathrm{~N}_{;} F_{1,8}=29.6, \mathrm{r}^{2}=0.79, \mathrm{p}<$ 0.001 ) and the slope suggests that the TE was $3.7 \%$ $\left(\mathrm{TE}=100\left[10^{3.4 \times \text { slope }}\right]\right)$. The relationship between species richness and $\delta^{15} \mathrm{~N}$ by size-class was highly significant (Fig. 2b; $\log _{10}$ species richness $=3.81-$ $\left.0.138 \delta^{15} \mathrm{~N}_{;} F_{1,8}=120.1, \mathrm{r}^{2}=0.94, \mathrm{p}<0.001\right)$. The slope suggests that the mean ratio of the number of predatorto-prey species was 0.34 (ratio $=10^{3.4 \times \text { slope }}$ ).

Given that the high levels of fishing mortality observed in the North Sea are likely to reduce biomass and production in large body-mass classes, we tested 

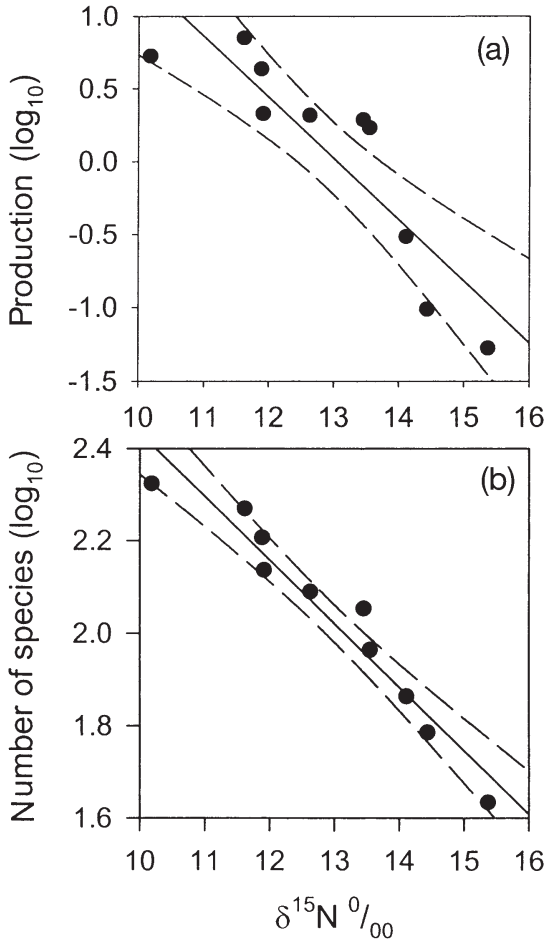

Fig. 2. Relationships between (a) $\log _{10}$ production $\left(\mathrm{g} \mathrm{m}^{-2} \mathrm{yr}^{-1}\right)$ and weighted mean $\delta^{15} \mathrm{~N}(\%)$, and (b) $\log _{10}$ species richness (number of species by $\log _{2}$ body-mass class) and weighted mean $\delta^{15} \mathrm{~N}(\%)$

the relationship between production and $\delta^{15} \mathrm{~N}$ when the larger body-mass classes were excluded from the analyses (Fig. 3). When individuals with a body mass $>1024 \mathrm{~g}$ were excluded, estimated transfer efficiency rose to $5.7 \%$. When individuals with body masses $>512$ and $>256 \mathrm{~g}$ were excluded, the estimated transfer efficiencies rose to 12.4 and $27.1 \%$ respectively (Fig. 3).

Since isotopic fractionation may not be $3.4 \%$, we calculated the effects of variations in fractionation on our estimates of TE (Fig. 4a), predator-prey body-mass ratios (Fig. $4 \mathrm{a}$ ) and the mean ratio of the number of predator-to-prey species (Fig. 4b). Fig. 4 shows that a lack of knowledge or inaccurate assumptions about the degree of fractionation of $\delta^{15} \mathrm{~N}$ in the ecosystem would influence the outputs of our analyses.

\section{DISCUSSION}

Size-based analyses can be coupled with nitrogen stable isotope $\left(\delta^{15} \mathrm{~N}\right)$ estimates of trophic level by bodymass class to estimate TE, mean predator-prey bodymass ratios and the mean ratio of the number of predator-to-prey species. We have shown that TE can be estimated without estimates of predator-to-prey body- mass ratios, and our estimates of TE are comparable with those derived from ecosystem models (Christensen \& Pauly 1993, Baumann 1995). Moreover, our approach gives mean predator-to-prey body-mass ratios as outputs, and these could be used to validate predator-to-prey body-mass ratios predicted from diet studies (Hahm \& Langton 1984, Jennings et al. 2001b).

Analyses of the structure and function of ecosystems on large scales are inevitably ambitious, due to difficulties in sampling, identifying ecosystem boundaries, quantifying the import and export of production, and understanding the impacts of predators that are not included in the analyses (humans, seabirds, marine mammals; Steele 1974, Mann \& Lazier 1986, Sherman \& Alexander 1986, Bax 1991). Our approach relied on some largely untested assumptions about sampling efficiency, losses of biomass and production due to fishing, the extent to which predator-prey interactions in the study area are independent of those outside the area, and the fractionation of $\delta^{15} \mathrm{~N}$. Quantitative estimates of abundance depend on the efficiency of sampling gears, and efficiency is not well known for most of the species and size-classes that are caught in nets. As a result, we assumed constant catchability and availability for all size-classes. This could result in underestimates or overestimates of biomass and production for some size-classes, and thus bias our estimates of TE. Existing species-based models suffer from the same concerns about abundance estimation for diverse groups of animals that have to be sampled with different gears. The lack of good catchability and availability estimates for most sampling gears will continue to hamper ecosystem analyses.

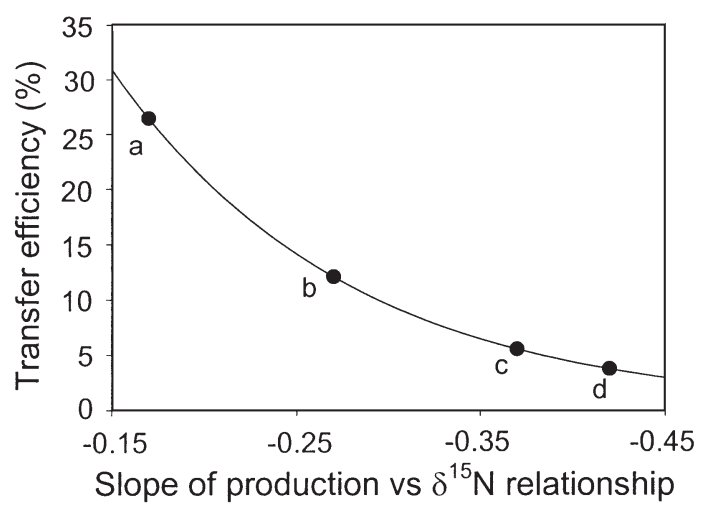

Fig. 3. Functional relationship between transfer efficiency and slope of the relationship between $\log _{10}$ production $\left(\mathrm{g} \mathrm{m}^{-2} \mathrm{yr}^{-1}\right)$ and mean $\delta^{15} \mathrm{~N}(\%)$. Fractionation of $\delta^{15} \mathrm{~N}(\%)$ with trophic level is assumed to be $3.4 \%$. Circles a-d show how estimates of transfer efficiency change in relation to the size range of animals included in the analyses: $\mathrm{a}=2-256 \mathrm{~g}$ included, $\mathrm{b}=2-512 \mathrm{~g}$ included, $\mathrm{c}=2-1024 \mathrm{~g}$ included, $\mathrm{d}=2-2048 \mathrm{~g}$ included 
Theorists suggest that TE may decrease at higher trophic levels and, by fitting a linear model to the production vs $\delta^{15} \mathrm{~N}$ relationship across all size classes, we have ignored this effect. However, the variance around our relationship, which we largely attribute to changing but unquantified catchability at body size and our relatively low levels of replication, meant that we could not reliably fit more complex models. Our approach may provide more accurate estimates of TE in areas that are less heavily fished and with smaller size-classes of animals that could be sampled more reliably. Reductions in biomass and, at high levels of mortality, production due to fishing will increase the slope of the production size-spectrum and reduce apparent TE. For this reason we repeated our analyses after excluding the production of larger fishes (SizeClasses 256 to 512 g, 512 to $1024 \mathrm{~g}$ and 1024 to $2048 \mathrm{~g}$ ). The estimates of TE, when these classes were excluded, spanned the range recorded for many marine ecosystems (Baumann 1995). A useful development of the present approach would be to develop a size-based model of the effects of fishing on production, in order to create a theoretical production vs $\delta^{15} \mathrm{~N}$ relationship and a theoretical TE for an unfished community.

Another potential bias was the potentially inadequate sampling of larger pelagic species (predominantly herring and mackerel in body mass classes 128 to $512 \mathrm{~g}$ ). These species feed at relatively low trophic levels and can be highly abundant in the study area. However, sampling may have been inadequate because they are seasonal visitors to the study area and their catchability and availability to trawl gears is lower than that of many demersal species. If the abundance of larger pelagic species was greater than our sampling suggests, then this would have increased the estimated predator-prey size ratio. Moreover, the inadequate sampling of larger pelagic species could contribute to the observed fall in total production with body size, and would mean that out estimates of transfer efficiency (calculated across body mass classes that include fish of 128 to $512 \mathrm{~g}$ ) are too low.

The size-based approaches we have used assume that predator-prey relationships are principally determined by body size and that omnivory is widespread. There are good theoretical and empirical reasons to adopt size-based approaches (Kerr \& Dickie 2001), but predator-prey relationships are constrained by many factors other than body size (Pimm et al. 1991, Hall \& Raffaelli 1993), and our analyses are necessarily approximations of a more complex reality. While existing knowledge of the feeding habits of the larger fishes in the North Sea ecosystem is extensive and shows that the main pathways of energy transfer are size-based and that omnivory is widespread (e.g. Christensen 1995), some of the larger benthic infaunal species are
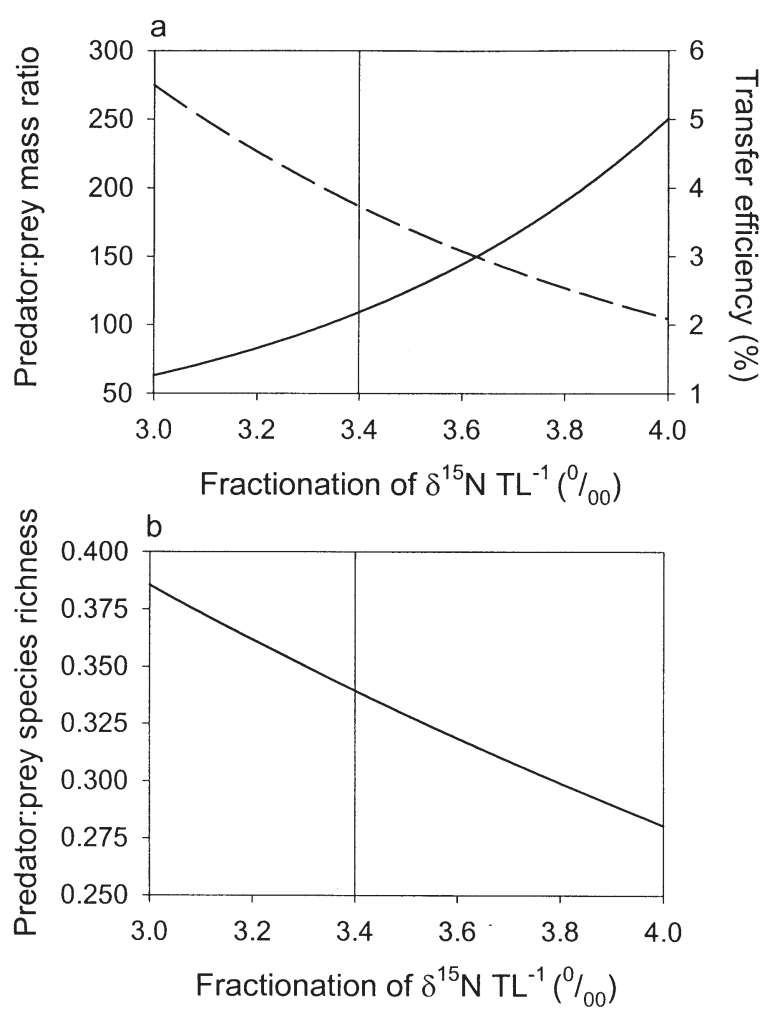

Fig. 4. Effects of assumptions about degree of fractionation of $\delta^{15} \mathrm{~N}(\%)$ with trophic level (TL) on (a) transfer efficiency (broken line) and predator-prey body-mass ratios (continuous line), and (b) mean ratio of the number of predator-to-prey species. Vertical lines in both graphs correspond to assumed fractionation of $3.4 \%$ per trophic level

unlikely to be components of size-based food webs. These larger benthic infauna include the spatangoid urchins that were excluded from this analysis, but could also include larger bivalves, such as Arctica islandica, which are only likely to be accessible to predators when damaged or exposed by trawling disturbance.

The biomass size-spectrum we compiled from the core, dredge, net and acoustic abundance estimates is effectively linear. Since we compiled the spectrum for animals that ranged in body mass over 3 orders of magnitude, we could be looking at part of a continuous spectrum or at part of a dome that corresponds to secondary scaling in the overall (from phytoplankton to large fishes) size spectrum (Sprules \& Goyke 1994). Many aquatic size-spectra exhibit secondary scaling as biomass domes for phytoplankton, zooplankton and fishes, but the evidence for this has mostly been acquired from theoretical studies and studies in lakes (Kerr \& Dickie 2001). In shallow marine environments such as the central North Sea, any secondary scaling in the spectrum may be less pronounced and the spectrum more continuous. This may be because lake 
organisms can be classified into size groups that have a relatively limited range of life history traits and morphologies (Neill 1994), while our observations suggest that the range of morphologies and trophic levels of organisms in the central North Sea is wider. For example, the body-size ranges of the abundant benthic invertebrate fauna span the size range between large planktonic invertebrates and the small pelagic and demersal fishes. If biomass and trophic spectra are more continuous in the North Sea than in lakes, then the effects of predation on the food web will be more diffuse and apply across a wider range of trophic levels. This may explain differences in the significance of top-down control in regulating food web structure. In most lake ecosystems, there are strong and predictable effects of changes in predator abundance on the ecosystem (Carpenter et al. 1987), while these effects appear to be weaker and more transient in the many marine systems (Hallowed et al. 2000, Reid et al. 2000). Given that the presence and strength of secondary scaling in size-spectra will have a key impact on our interpretation of food web processes, further attempts to compile aggregate size-spectra for marine systems are needed. However, as we stressed previously, this will require much improvement in the quantitative sampling of epifauna and fishes.

We assumed that $\delta^{15} \mathrm{~N}$ was linearly related to trophic level, and a $\delta^{15} \mathrm{~N}$ enrichment of $3.4 \%$ per trophic level (Minagawa \& Wada 1984, Post 2002). However, there is variation around the mean fractionation of $3.4 \%$, and this has prompted calls for further experimental validation (e.g. Gannes et al. 1997, Adams \& Sterner 2000). Such validation has not been completed, and is probably not feasible, in a complex open-sea food web, although 9 mo experimental rearing of bass Dicentrarchus labrax fed on sandeel Ammodytes marinus and dab Limanda limanda diets at a range of ambient North Sea temperatures has shown that mean fractionation with both diets was $3.4 \%$ (C. Sweeting unpubl. data). The present experiments provide further support for the assumed fractionation, but are based on a situation where food was unlimited. We accept that food limitation, changes in dietary nitrogen content and changes in growth rate may influence fractionation (e.g. Adams \& Sterner 2000), and we have shown how changes in fractionation would affect our results. To allow better interpretation of our results, and in order to assess the relative merits of TE predictions based on stable isotope data and estimates of predatorprey body-mass ratios, further experimental validation of $\delta^{15} \mathrm{~N}$ fractionation is required.

Our estimates of the mean ratio of the number of predator-to-prey species are not the direct equivalent of ratios that have been estimated in other systems (e.g. Jeffries \& Lawton 1985), because not all the species at one point on the trophic continuum will eat all smaller species. Thus, a number of invertebrate species are detritivores or herbivores and a proportion of planktivorous pelagic fishes (sandeel, sprat, herring) will not eat bottom-dwelling species once they have settled from the plankton. However, most larger fishes are generalists and would prey on most species 2 orders of magnitude smaller. Our estimate of the mean ratio of the number of predator-to-prey species (0.34) is similar to ratios reported for freshwater food webs (range 0.29 to 0.48 , mean 0.36: Jeffries \& Lawton 1985). Our methods for describing the ratio of the numbers of predator-to-prey species could readily be applied to other marine ecosystems, although they are only applicable across size ranges where species richness decreases consistently with increasing body size.

The relationship between $\delta^{15} \mathrm{~N}$ and $\log _{2}$ body mass is size-invariant and, if we assume that $\delta^{15} \mathrm{~N}$ fractionation is independent of body size, the relationship can be used to calculate mean predator-prey mass ratios. Our results show that the mean predator-prey mass ratio $(109: 1)$ is lower than that estimated for a community of bottom-dwelling fishes and epibenthos in the North Sea (434:1), but infauna and small pelagic fishes were not included in the community study (Jennings et al. 2002). Our study has shown that infauna and small pelagic fishes dominate the biomass of the smallest size-class, have low $\delta^{15} \mathrm{~N}$, and are consumed by many bottom-dwelling fishes and invertebrates. Predator-toprey mass ratios are notoriously difficult to calculate from diet analysis (Ursin 1973, Hahm \& Langton 1984), whereas predictions based on stable isotope analysis can account for animals feeding on complex and changing multispecies diets because they integrate changes in diet over time (Polunin \& Pinnegar 2002). Our estimate of the mean predator-prey mass ratio falls within the range of $1: 10^{2}$ to $10^{3}$ that is assumed for many marine ecosystems (Cushing 1975).

Our size- and stable isotope-based methods of ecosystem analysis make a number of gross simplifications about the size-based nature of predator-prey relationships, the significance of omnivory in marine ecosystems, and the estimation of trophic level from nitrogen stable isotope analysis. However, they do provide a basis for assessing the structure and function of ecosystems at large spatial scales. We conclude that sizebased analyses of the structure of a marine ecosystem can be coupled with nitrogen stable isotope estimates of trophic level by body mass to estimate TE, mean predator-prey body-mass ratios and the ratio of the number of predator-to-prey species, but that the results must be interpreted with caution and with reference to the underlying assumptions.

Encouragingly, our estimates of TE and mean predator-prey body-mass ratios are broadly consistent with 
those obtained from costly and labour-intensive dietand ecosystem-modelling studies. Coupled analyses of size and trophic structure may provide another method for validating ecosystem models and assessing human impacts on marine ecosystems.

Acknowledgements. We thank Dan Duplisea for comments on the manuscript, Richard Ayers, Trevor Boon, Grant Course, Nic Denney, Tracy Dinmore, Chris Firmin, Paul Hudson, Michaela Schratzberger, Chris Sweeting and the officers and crew of RV 'Corystes' and RV 'Cirolana' for their efforts at sea and Anne Bruce and Rowan White for conducting the stable isotope analyses. We thank the CEFAS, the DEFRA MF07 'Impacts of Fishing' programme and the US National Science Foundation for funding this research and we are grateful to the members of SCOR IOC NMFS WG 119 for constructive discussions.

\section{LITERATURE CITED}

Adams TS, Sterner RW (2000) The effect of dietary nitrogen content on trophic level ${ }^{15} \mathrm{~N}$ enrichment. Limnol Oceanogr 45:601-607

Banse K, Moser S (1980) Adult body mass and annual production/biomass relationships of field populations. Ecol Monogr 50:355-379

Baumann M (1995) A comment on transfer efficiencies. Fish Oceanogr 4:264-266

Bax NJ (1991) A comparison of the biomass flow to fish, fisheries and mammals in six marine ecosystems. ICES Mar Sci Symp 193:217-224

Boudreau PR, Dickie LM, Kerr SR (1991) Body-size-spectra of production and biomass as system-level indicators of ecological dynamics. J Theor Biol 152:329-339

Boyle PR, Bolettzky Sv (1996) Cephalopod populations: definition and dynamics. Phil Trans R Soc Lond B 351:985-1002

Brey $\mathrm{T}$ (1999) Growth performance and mortality in aquatic macrobenthic invertebrates. Adv Mar Biol 35:153-223

Briand F, Cohen JE (1984) Community food webs have scale invariant structure. Nature 302:264-267

Cabana G, Rasmussen JB (1996) Comparison of aquatic food chains using nitrogen isotopes. Proc US Natl Acad Sci 93: 10844-10847

Carpenter SR, Kitchell JF, Hodgson JR, Cochran PA and 6 others (1987) Regulation of lake primary productivity by food web structure. Ecology 68:1863-1876

Christensen V (1995) A model of trophic interactions in the North Sea in 1981, the year of the stomach. Dana 11:1-28

Christensen V, Pauly D (1993) Trophic models of aquatic ecosystems. ICLARM Conf Proc 26:390

Cohen JE, Pimm SL, Yodzis P, Saldaña J (1993) Body sizes of animal predators and animal prey in food webs. J Anim Ecol 62:67-78

Cushing DH (1975) Marine ecology and fisheries. Cambridge University Press, Cambridge

Dickie LM, Kerr SR, Boudreau PR (1987) Size-dependent processes underlying regularities in ecosystem structure. Ecol Monogr 57:233-250

Duarte CM, Cebrián J (1996) The fate of marine autotrophic production. Limnol Oceanogr 41:1758-1766

Duplisea DE, Kerr SR (1995) Application of a biomass size spectrum model to demersal fish data from the Scotian shelf. J Theor Biol 177:263-269

Foote KG, Knudsen HP, Vestnes G, MacLennan DN, Sim- monds ED (1987) Calibration of acoustic instruments for fish density estimation: a practical guide. ICES Co-op Res Rep 144

France R, Chandler M, Peters R (1998) Mapping trophic continua of benthic food webs: body size $\delta^{15} \mathrm{~N}$ relationships. Mar Ecol Prog Ser 174:301-306

Fry B, Quinones RB (1994) Biomass spectra and stable-isotope indicators of trophic level in zooplankton of the NW Atlantic. Mar Ecol Prog Ser 112:201-204

Gaedke U, Straile D (1994) Seasonal changes of trophic transfer efficiencies in a plankton food web derived from biomass size distributions and network analysis. Ecol Model 75:435-445

Gannes L, O'Brien D, del Rio C (1997) Stable isotopes in animal ecology: assumptions, caveats, and a call for more laboratory experiments. Ecology 78:1271-1276

Hahm W, Langton R (1984) Prey selection based on predator/prey weight ratios for some northwest Atlantic fish. Mar Ecol Prog Ser 19:1-5

Hall SJ, Raffaelli DG (1993) Food webs: theory and reality. Adv Ecol Res 24:187-239

Hallowed AB, Bax N, Beamish R, Collie J, Fogarty M, Livingston P, Pope JG, Rice JC (2000) Are multispecies models an improvement on single-species models for measuring fishing impacts on marine ecosystems? ICES J Mar Sci 57:707-719

Heip C, Basford D, Craeymeersch JA, Dewarumez JM and 12 others (1992) Trends in biomass, density and diversity of North Sea macrofauna. ICES J Mar Sci 49:13-22

Hobson KA, Welch HE (1992) Determination of trophic relationships within a high arctic marine food web using delta-C-13 and delta-N-15 analysis. Mar Ecol Prog Ser 84: $9-18$

Jeffries JJ, Lawton JH (1985) Predator-prey ratios in communities of freshwater invertebrates: the role of enemy free space. Freshw Biol 15:105-112

Jennings S, Reynolds JD, Mills SC (1998) Life history correlates of responses to fisheries exploitation. Proc R Soc Lond B 265:333-339

Jennings S, Dinmore TA, Duplisea DE, Warr KJ, Lancaster JE (2001a) Trawling disturbance can modify benthic production processes. J Anim Ecol 70:459-475

Jennings S, Pinnegar JK, Polunin NVC, Boon T (2001b) Weak cross-species relationships between body size and trophic level belie powerful size-based trophic structuring in fish communities. J Anim Ecol 70:934-944

Jennings S, Pinnegar JK, Polunin NVC, Warr KJ (2002) Linking size-based and trophic analyses of benthic community structure. Mar Ecol Prog Ser 226:77-85

Kerr SR (1974) Theory of size distribution in ecological communities. J Fish Res Board Can 31:1859-1862

Kerr SR, Dickie LM (2001) The biomass spectrum: a predatorprey theory of aquatic production. Columbia University Press, New York

Knijn RJ, Boon TW, Heessen HJL, Hislop JRG (1993) Atlas of North Sea fishes. Int Counc Explor Sea Coop Res Rep 194: 268

Link JS (2002) Does food web theory work for marine ecosystems? Mar Ecol Prog Ser 230:1-9

MacLennan DN, Fernandes P (2000) Acoustic definitions, units and symbols. Report of the working groups on fisheries acoustics sceince and technology. Int Counc Explor Sea Comm Meet 2000/B:04

MacLennan DN, Simmonds EJ (1992) Fisheries acoustics. Chapman \& Hall, London

Mann KH, Lazier JRN (1996) Dynamics of marine ecosystems. Blackwell Science, London 
Minagawa M, Wada E (1984) Stepwise enrichment of ${ }^{15} \mathrm{~N}$ along food chains: further evidence and the relation between ${ }^{15} \mathrm{~N}$ and animal age. Geochem Cosmochim Acta 48:1135-1140

Neill WM (1994) Spatial and temporal scaling and the organisation of limnetic communities. In: Giller PS, Hildrew AG Rafaelli DG (eds) Aquatic ecology: scale, pattern and process. Blackwell Scientific Publications, Oxford, p 189-231

Owens NJP (1987) Natural variations in ${ }^{15} \mathrm{~N}$ in the marine environment. Adv Mar Biol 24:389-451

Pauly D, Christensen V (1995) Primary production required to sustain global fisheries. Nature 374:255-257

Peterson BJ, Fry B (1987) Stable isotopes in ecosystem studies. Annu Rev Ecol Syst 18:293-320

Pimm SL (1982) Food webs. Chapman \& Hall, London

Pimm SL, Lawton JH, Cohen JE (1991) Food web patterns and their consequences. Nature 350:669-674

Platt T, Denman K (1978) The structure of the pelagic marine ecosystem. Rapp P-v Réun Cons Int Explor Mer 173:60-65

Polunin NVC, Pinnegar JK (2002) Trophic ecology and the structure of marine food webs. In: Hart PJ, Reynolds JD (eds) Handbook of fish and fisheries. Blackwell Science, Oxford

Pope JG, Stokes TK, Murawski SA, Iodoine SI (1988) A comparison of fish size composition in the North Sea and on Georges Bank. In: Wolff W, Soeder CJ, Drepper FR (eds) Ecodynamics: contributions to theoretical ecology. Springer-Verlag, Berlin, p 146-152

Pope JG, Shepherd JG, Webb J (1994) Successful surf-riding on size-spectra: the secret of survival in the sea. Phil Trans R Soc Lond B 343:41-49

Post DM (2002) Using stable isotopes to estimate trophic position: models, methods and assumptions. Ecology 83: 703-718

Post DM, Pace ML, Hairston NG (2000) Ecosystem size deter-

Editorial responsibility: Otto Kinne (Editor),

Oldendorf/Luhe, Germany mines food-chain length in lakes. Nature 405:1047-1049

Preston T, Owens NJP (1983) Interfacing an automatic elemental analyser with an isotope ratio mass spectrometer: the potential for fully automated total nitrogen and nitrogen-15 analysis. Analyst (Lond) 108:971-977

Reid PC, Battle EJV, Batten SD, Brander KM (2000) Impacts of fisheries on plankton community structure. ICES J Mar Sci 57:495-502

Rice J, Gislason H (1996) Patterns of change in the sizespectra of numbers and diversity of the North Sea fish assemblage, as reflected in surveys and models. ICES J Mar Sci 53:1214-1225

Rolff C (2000) Seasonal variation in $\delta^{13} \mathrm{C}$ and $\delta^{15} \mathrm{~N}$ of sizefractionated plankton at a coastal station in the northern Baltic proper. Mar Ecol Prog Ser 203:47-65

Sheldon RW, Prakash A, Sutcliffe WH (1972) The size distribution of particles in the Ocean. Limnol Oceanogr 17: $327-340$

Sherman K, Alexander LM (1986) Variability and management of large marine ecosystems. Westview Press, Boulder

Sparholt H (1990) An estimate of the total biomass of fish in the North Sea. J Cons Perm Int Explor Mer 46:200-210

Sprules WG, Goyke AP (1994) Size-based structure and production in the pelagia of Lakes Ontario and Michigan. Can J Fish Aquat Sci 51:2603-2611

Staniland IJ, Hart PJB, Bromley PJ (2001) The regurgitation of stomach contents in trawl caught whiting: evidence of a predator size effect. J Fish Biol 59:1430-1432

Steele JH (1974) The structure of marine ecosystems. Blackwell Scientific Publications, Oxford

Thiebaux ML, Dickie LM (1992) Models of aquatic biomass size-spectra and the common structure of their solutions. J Theor Biol 159:147-161

Ursin E (1973) On the prey size preferences of cod and dab. Medd Komm Dan Fisk-Havunders Ser Fiskeri 7:85-98

Submitted: February 20, 2002; Accepted: May 17, 2002

Proofs received from author(s): August 12, 2002 